\title{
MILITANTES, IRMÃOS E CABOS ELEITORAIS: VIDA ASSOCIATIVA E TERRITÓRIO NAS PERIFERIAS DA CIDADE DE SÃO PAULO
}

Gilberto Geribola Moreno

\section{Introdução}

Entre os anos de 2010 e 2013 realizei intensa pesquisa etnográfica multissituada (Marcus 1995) na periferia da região Sul da cidade de São Paulo. Nela abordei cinco espaços associativos: a Sociedade São José Operário, associação ligada à Igreja Católica, cuja parte expressiva dos participantes é originária das Comunidades Eclesiais de Base, importante instrumento de organização popular nos anos 1970; a Associação Mulheres em Luta, originária dos Clubes de Mães e da luta pela legalização de terrenos nas periferias da cidade; a Associação Vila Conceição, ligada ao samba e ao futebol de várzea; o Sarau do Alfredo, encontro de poetas e artistas para expressão de suas produções culturais; a Associação Vila Zita, entidade com marcantes relações com um parlamentar e que se orienta pela prática de troca de favores com sua base eleitoral. ${ }^{1}$

Neste artigo me dedico à Associação Vila Conceição e ao sarau que lá se realizou entre os anos 2009/12 por iniciativa de um grupo de jovens militantes que não pertenciam à entidade. Apresentarei alguns relatos etnográficos que descrevem o encontro de dois personagens presentes atualmente nas periferias da cidade de São Paulo: os militantes e os irmãos. Um deles circula pelas periferias, dedicando-se ao universo da política, à vida associativa, à participação em partidos políticos e em movimentos sociais. De certo modo, pode estar em uma linha de continuidade com aqueles moradores que participaram dos movimentos sociais dos anos 1970/80.

O outro personagem, embora presente no cenário das periferias há muito tempo, adquiriu um novo status nos últimos anos, identificando-se como "irmão" a partir dos anos 2000, conquistando preeminência crescente desde essa data. Não são os fiéis frequentadores das diferentes denominações pentecostais e neopentecostais que proliferaram nas periferias e introduzi- 
ram novas formas de sociabilidade religiosa e que se tratam por irmãos por estarem irmanados na fé. Tampouco são os atores ligados ao movimento hip hop articulado em torno da música e da poesia e que emergiu com destaque a partir dos anos 1990 nas periferias. No interior desse grupo de estilo, os termos "mano" e "brother" são utilizados para se referir a seus participantes e como léxico de identificação com o movimento. Estas expressões não guardam semelhança com o termo "irmão" abordado neste trabalho e que diz respeito à forma de identificação daqueles que atuam no Primeiro Comando da Capital (PCC) - principal agremiação criminosa no estado - considerado o partido do crime segundo sua própria representação. ${ }^{2}$

O objetivo deste artigo é apresentar alguns atores presentes nas periferias da cidade de São Paulo que atuam no campo político e cultural, apontando suas interações ora de aproximação, ora de evitação ou afastamento e no contexto específico de uma associação de bairro. O artigo aponta as ambivalências presentes na experiência da vida associativa e das práticas políticas desenvolvidas por esses diferentes atores, em especial por jovens militantes dos movimentos sociais.

Os moradores das periferias participantes dos movimentos sociais foram personagens recorrentes no cenário político da cidade de São Paulo nos anos 1970/80. Esse fenômeno da participação popular se refletiu na produção das ciências sociais que enfatizavam a emergência desses atores no cenário político do período, contribuindo para o desenvolvimento urbano das periferias. Holston (2011) denomina de "cidadania insurgente" o conjunto de movimentos sociais desse período, compreendendo-o como um fator responsável pelo aumento da percepção dos moradores das periferias sobre a cidade, sobretudo quanto aos seus direitos civis, políticos e sociais na excludente sociedade brasileira. Outros autores (Sader 1988; Moisés 1978; Caldeira 1989; Durham 2004; Sposito 2010; Cardoso 2011, entre outros) enfatizam o papel político que esses movimentos sociais tiveram, com acentuada liderança de mulheres residentes nos bairros periféricos, ao pressionar o Estado por benfeitorias públicas, contribuindo para o recrudescimento da participação popular no cenário político do período autoritário e a consequente exigência de abertura política e conquista de direitos de cidadania.

Nas duas décadas subsequentes à abertura política, o tema da violência urbana ganhou relevância em decorrência do crescimento das taxas de criminalidade nas cidades brasileiras. O "paradoxo brasileiro" nesse período, segundo expressão de Peralva (2000), era a conjugação do processo de redemocratização do país com a consequente ampliação dos direitos de cidadania acompanhados pelo crescimento da violência nas grandes cidades. 
No início dos anos 2000, por meio de rebeliões nos presídios do estado de São Paulo e de uma megarrebelião nos presídios articulada com as ações nas ruas da capital paulista no ano de 2006, torna-se pública a existência do Primeiro Comando da Capital (PCC). A emergência no estado de São Paulo desse novo agente no mundo do crime $^{3}$ e suas relações com outras esferas do mundo social apontam não mais para um paroxismo entre as dimensões que compõem o "mundo do crime" e aquelas da sociedade abrangente. O dado importante é que, a partir da consolidação da presença do PCC nas periferias da cidade de São Paulo, um novo personagem começa a ganhar relevância social: os "irmãos".

No que tange aos movimentos sociais, segundo Dagnino (2004:198), no período pós-abertura ocorre uma crise discursiva desses movimentos que tem a ver com o campo das disputas políticas, mas também pelos significados e os referenciais políticos, como participação, cidadania, sociedade civil, democracia. Nesta conjuntura, alguns autores (Oliveira \& Rizek 2007; Telles \& Cabanes 2006; Telles 2009, entre outros) vão apontar a existência de um permanente estado de exceção nessa nova ordenação social consubstanciada na fragmentação do tecido social, enfatizando uma zona de sombras na qual a sociabilidade é marcada pela permeabilidade das fronteiras entre as dimensões do lícito e do ilícito, do legal e ilegal.

Em meu ambiente de pesquisa, estes dois atores - militantes e irmãos estabelecem certas relações no bojo da disputa pelo predomínio nos espaços associativos e no território. Essas disputas se desenvolvem no espaço público e são significadas pelos jovens militantes como um embate político a despeito da desigualdade de condições para a ação oriunda da possibilidade de uma das partes poder se utilizar da violência. ${ }^{4}$ No entanto, segundo eu pude constatar em minha pesquisa de campo, para os jovens militantes, a possibilidade do recurso à violência por parte de alguns moradores não é um elemento que inviabilize sua ação, sendo este recurso compreendido como um componente a mais a ser avaliado no conjunto de provas (Martuccelli \& Singly 2009; Martuccelli 2012) com que os militantes e os atores políticos se defrontam nas periferias.

Um dos espaços associativos que eu acompanhei foi a Associação Vila Conceição. Inicialmente, essa associação se dedicava apenas ao futebol de várzea, ao samba e a algumas práticas de lazer esporádicas, como shows de música sertaneja e almoços, com vistas principalmente à arrecadação de recursos financeiros. A partir de 2011, nas noites de terça-feira, passou a comportar o Sarau da Vila Conceição, evento organizado nos moldes de tantos outros saraus que acontecem nas periferias da cidade. ${ }^{5}$

Apresentarei alguns apontamentos da pesquisa etnográfica realizada na Associação Vila Conceição. Nesse espaço, o encontro entre militantes e 
irmãos foi recorrente durante meu trabalho de campo, possibilitando acompanhá-los em interação, momento privilegiado para a pesquisa etnográfica. As descrições que seguem são registros de meu caderno de campo e serão apresentadas com o sentido de expor as situações vividas pelos diferentes atores - irmãos, militantes e antropólogo - e refletir sobre elas. Espero assim poder ilustrar certas dinâmicas presentes na esfera da vida associativa dos moradores das periferias da cidade de São Paulo.

Ao elaborar minha pesquisa nas periferias da cidade de São Paulo, tomei como referência ser este trabalho uma compreensão possível, dentre outras, que diferentes etnógrafos desenvolveram e realizaram nesta região. É importante frisar que tanto a pesquisa que dá corpo a este artigo como o próprio artigo são o resultado de um olhar específico, orientado e marcado pela minha trajetória de pesquisador e das escolhas teóricas e metodológicas que fiz ao longo do trabalho. A inteligibilidade que esta etnografia proporciona sobre as vidas desses "outros" é em grande medida, pode-se dizer, circunstancial em face do momento da pesquisa e das relações possíveis entre os grupos pesquisados e o antropólogo. Portanto, é fruto da experiência e da reflexividade proporcionadas pelo encontro dos personagens que compõem este trabalho.

\section{Militantes e irmãos}

Durante minha pesquisa acerca da vida associativa nas periferias da cidade de São Paulo eu acompanhei o Sarau da Vila Conceição, uma atividade desenvolvida por um grupo de jovens militantes que reúne membros da Associação Mulheres em Luta, Sarau do Alfredo e do movimento por moradia e transporte da região Sul da cidade de São Paulo. De maneira similar aos demais saraus realizados nas periferias, este tem seu mestre de cerimônias. Seu nome é Bruno, jovem que atua nos movimentos sociais da região, tais como movimento por moradia, transporte e incentivos públicos à produção cultural das periferias. Segundo suas declarações, ao fazer o sarau na Vila Conceição, o objetivo era "promover a cultura e a discussão política na quebrada". Em diferentes situações Bruno enfatiza: "Eu cresci aqui. Fazer o sarau é uma maneira de dar um retorno pra comunidade. De trazer alguma coisa pra cá". Ainda de acordo com suas declarações: "Eu busquei me articular com o pessoal que já tem experiência com sarau, tipo o Alfredo e o Maurão. ${ }^{6}$ Aí eu vim aqui e troquei umas ideias com o Márcio (36) e o Dirceu (32), ${ }^{7}$ e eles toparam".

Embora realizem uma atividade cultural, o objetivo declarado pelo grupo de jovens organizadores do Sarau da Vila Conceição "é estabelecer uma ação 
política através do sarau e da atuação junto aos moradores" (Bruno). Essa atuação comporta diferentes práticas que passam pelo sarau, mas também pela realização de mutirões de limpeza, reivindicação de melhorias e festas em datas específicas. Esses militantes não têm relações orgânicas com a Associação Vila Conceição, de modo que não participam das atividades ali desenvolvidas desde sua fundação: o futebol e o samba. Tampouco se envolveram nelas a partir de sua inserção na associação por meio da organização do sarau. O samba e o futebol são atividades de interesse exclusivo dos membros originários da associação. Segundo o seu idealizador, "fazer o sarau foi uma maneira de estabelecer uma relação política com a comunidade. De propor coisas pra serem feitas. Apresentar outras realidades que não só esta que eles vivem".

O sarau iniciou suas atividades em novembro de 2009 às terças-feiras. Suas apresentações têm início por volta das 21 horas $^{8}$ e ocupam o salão principal da associação. Pouco antes desse horário já se observa a presença de seu público, composto, em sua grande maioria, por jovens que não pertencem à "comunidade". Esses jovens formam a rede de coletivos culturais que se organizam em outros bairros das periferias. O sarau é divulgado por meio das redes sociais e do informativo "Agenda da Periferia", ${ }^{9}$ organizado pela ONG Ação Educativa.

Durante o Sarau da Vila Conceição é seguida uma ritualística que enfatiza a importância dos movimentos sociais, a valorização da cultura produzida nas periferias, o estímulo à leitura e à posse de livros, que estão sempre presentes nos saraus que acompanhei. Além de serem expostos, os livros são também distribuídos aos participantes, que são incentivados a manuseá-los e a tomá-los para si, em alguns casos gratuitamente. Neste quesito, o Sarau da Vila Conceição reproduz as dinâmicas observadas em outros saraus das periferias paulistanas.

Nas aberturas do sarau, Bruno sempre usava o bordão: "Boa noite, Sarau da Vila Conceição. Boa noite, periferias e quebradas desse Brasil". Inicialmente, Bruno apresentava o sarau como "uma iniciativa para a comunidade", porém, à medida que novas e constantes edições foram se seguindo, ele passou a afirmar que "o Sarau da Vila Conceição é uma atividade organizada pelo Luta Popular, um coletivo que organiza a luta na quebrada, os jovens e a cultura".

Logo após a abertura, Bruno estimula a plateia para que alguém faça "um depoimento sobre a comunidade". Se ninguém se manifesta, mais uma vez Bruno pergunta: "Alguém quer dar um informe sobre a quebrada, fazer um depoimento? Fiquem à vontade, o microfone é nosso, estamos em casa, pode falar o que quiser". Em geral, as pessoas permanecem caladas e Bruno discursa sobre algum tema que "afeta a vida da gente na quebra- 
da". Questões envolvendo ações da polícia são recorrentes, dada a atuação policial na região que tem reiteradamente redundado em violência seguida de morte. Depois desse discurso inicial, apresenta-se uma atração musical, que costuma ser uma composição do universo musical hip hop. As músicas são intercaladas por apresentações de teatro e se declamam poesias. Desde o início, poetas, artistas e frequentadores de outros saraus passaram a se deslocar de suas regiões de origem para prestigiar o Sarau da Vila Conceição em um movimento de composição de plateia que, segundo expressão de Márcia (25, AML/MLP), “a gente precisa fazer público pra gente mesmo num primeiro momento".

Apesar do caráter de apresentação artístico-cultural, o encontro é marcado por uma série de discursos críticos a respeito da desigualdade social, da opressão e da necessidade de "defesa de todos que são oprimidos. De todos os Pinheirinhos ${ }^{10}$ que temos por toda parte nesse país e nas suas várias quebradas". Seguindo essa tônica, muitos encontros são definidos mais por discursos de cunho político do que pela declamação de poemas ou as apresentações artísticas. Esses discursos, que abordam questões referentes à desigualdade social, ao racismo, à violência policial, à moradia, são acompanhados por jovens ligados ao Movimento Luta Popular ${ }^{11}$ e conjugados a uma nova frequência na associação de jovens de outras localidades. Os discursos introduziram alguns contrapontos em relação às dinâmicas de sociabilidade corriqueiras da associação em torno do samba e do futebol de várzea. Voltada exclusivamente para atividades naquele pedaço, a associação passou a comportar discursos controversos até mesmo quanto às suas práticas e alianças políticas, e se propôs a debater aspectos gerais das "lutas políticas do povo brasileiro dessa e de tantas outras quebradas do Brasil" (Bruno). Assim, observa-se que nas noites de terça-feira os jovens residentes no local, frequentadores habituais da associação, passaram a se reunir em um bar próximo, não participando do sarau.

Os militantes afirmam a importância de serem moradores daquela região, realçando as características culturais e sociais positivas do lugar, caracterizadas, segundo eles, pela luta. Assim, dizia o mestre de cerimônias em uma noite quente de terça-feira: "a gente é pela gente mesmo. Se a gente não se unir, a gente não vai conquistar nossos direitos. Não adianta dormir no barulho de quem vem aqui prometendo mundos e fundos. Somos nós que temos que fazer por nós". Algumas vezes os discursos dos militantes se voltam contra as ações promovidas pelo vereador Antunes, político muito influente na região, e seus correligionários, ${ }^{12}$ expressando o posicionamento do grupo de militantes do sarau sobre aqueles que eles consideram ter legitimidade para atuar naquele pedaço: eles mesmos. Para os militantes, ser da região é 
um fator muito importante para atuar politicamente naquela quebrada. Com isso, defendem que a ação política no bairro deve ser exercida por aqueles que são moradores da região, evitando e até mesmo impossibilitando a entrada de pessoas - militantes ou políticos profissionais - de fora do bairro.

Ao rechaçarem a entrada de "gente que não é da quebrada", os militantes, sem o saber, professavam o mesmo sentimento que os membros e os frequentadores originais da associação têm em relação a eles e aos participantes do sarau, ${ }^{13}$ pois os membros e frequentadores originários da associação se consideram da "comunidade" e da sua associação e classificam os militantes como gente de fora. Já os militantes, baseados na noção de periferia, estabelecem outra classificação na qual eles também se consideram da "comunidade", considerando "estrangeiro" quem vem de fora da periferia. Assim se desenvolve um jogo de espelhos em que as posições de dentro e de fora vão se renovando à medida que novas pessoas chegam ao pedaço; recém-chegados se consideram "estabelecidos", mas são observados pelos antigos membros como parte do grupo de "outsiders", abrindo a possibilidade para novas segmentações no interior da entidade.

Um episódio ilustra essa relação controversa dos militantes com quem "é de fora da quebrada". Duas ONGs ${ }^{14}$ sediadas na cidade do Rio de Janeiro e com grande visibilidade na esfera pública estiveram na região procurando estabelecer parcerias com lideranças e associações. O objetivo dessas organizações era iniciar trabalhos voltados para os moradores daquela localidade nos mesmos moldes dos realizados em seu estado de origem. Segundo relatos, alguns emissários das organizações cariocas percorreram as associações de moradores do bairro propondo parcerias para uma atuação conjunta. Tentavam, me disse Pedro (35/AML), "exportar o trabalho que eles têm no Rio. Só que aqui é mais complicado, porque a gente não vai deixar os caras passarem por cima do nosso trabalho". Corroborando a mesma opinião, Rômulo (28/AML) disse:

Os caras tiveram na Casa da Mulher para trocar umas ideias. Trocar ideias é modo de dizer, porque eles já chegaram com tudo pronto. Eles queriam que a gente trampasse pra eles. Pra que a gente vai querer isso se a gente já tem nosso trampo aqui? Os caras vieram numas de que aqui não tinha trabalho de militante, que não tinha nada e quebraram a cara.

Os organizadores do sarau mantêm relações com rappers do Morro Santa Marta do Rio de Janeiro. Durante a visita das ONGs dois rappers cariocas estavam na região e fizeram uma apresentação no sarau e teceram duras críticas à atuação das organizações que tentavam adentrar aquele 
espaço. Os ânimos estavam exaltados em relação à forma com que se deu a aproximação junto às associações e, no calor do momento, os rappers proclamaram: "Essas entidades têm a pretensão de representar todos os favelados. Quem eles pensam que são?". Falando para um público externo à Vila Conceição, eles perguntavam: "Quem deu esse direito a eles? Ninguém representa vocês a não ser vocês mesmos. É isso aí!!!! Quem escolheu eles pra representantes?". Nesse momento, Pedro, que nesse dia era o MC do sarau, assumiu a palavra:

- É. Eles vieram aqui com essa conversa. Já tinham até um plano pronto para agir na comunidade. Não deixamos não. Aqui a comunidade "é nóis", não esses caras que querem chegar dizendo o que tem que ser feito.

- Nem nós. Nós temos a mesma origem, somos moradores de favela - disse o rapper carioca - mas estamos aqui no maior respeito com a comunidade. Nós estamos aqui mostrando nossa arte. Dando nosso recado. A comunidade nos escuta se quiser.

Nesta transcrição evidencia-se uma pluralidade de lógicas de acesso à comunidade e, em particular, à associação. O rapper estabelece uma relação na qual se apresenta como um de fora próximo, que sabe chegar na comunidade. Negro, rapper, morador de favela, o rapaz mobiliza uma série de elementos que sinalizam a sua compreensão de certa etiqueta ${ }^{15}$ que rege as relações naquele pedaço. A noção de respeito é fundamental e, ao que parece, não fora observada na aproximação dos rapazes das organizações do Rio de Janeiro. Mesmo sendo um convidado, o rapper demonstra saber que a última palavra é da comunidade no que tange à recepção de seu discurso e de sua arte. Ao contrário, aquele que é de fora e chega querendo mandar estabelece uma relação "de fora distante" produzida pela inabilidade e a falta de etiqueta no trato com os de dentro. A categoria que melhor representa essa tensão é o respeito. Neste caso, propriamente, foi a falta de respeito que contribuiu para se criarem as dificuldades de acesso à comunidade.

A queixa que eu ouvi fazia referência à aproximação e à tentativa de entrada dos membros das ONGs nas associações nas quais meus interlocutores atuam sem a intermediação de um morador, fato que evidencia outra transgressão à etiqueta de acesso às associações ou às diferentes localidades. ${ }^{16}$ Infelizmente, eu não tive acesso aos membros das ONGs cariocas para conferir essa queixa. Outro ponto que pode ser destacado é o jogo de disputa pelo território no qual se desenvolve a ação. Os depoimentos citados permitem pensar no estabelecimento e na defesa de certa área de atuação política por parte dos jovens militantes que se manifestavam no sarau. 
Não é apenas em relação às entidades ou aos políticos de fora do pedaço que se opõe parte dos membros das associações ou os militantes locais. Há também uma atitude de evitação diante das pessoas que sejam de fora, embora residam na região. Nesse caso, as manifestações partem dos membros da associação e de moradores com algum grau de aproximação com a entidade.

Nos dias de sarau evidencia-se a presença de pessoas que são de outros locais, ao mesmo tempo em que se percebe a ausência dos moradores habituais frequentadores da associação. Eu pude observar que esses moradores ficavam no bar vizinho à sede da associação ou no churrasquinho localizado algumas casas acima. Alguns marcadores sociais de diferença ficam claros à observação. Por exemplo, aumento da presença feminina no interior e em frente à sede da associação. Ocorre uma diminuição de negros e aumento perceptível de brancos. Saem as camisetas com alusões às marcas da periferia e entram as que estampam mensagens políticas e de movimentos populares. Para mim ficava a impressão de que o sarau introduzia elementos que não faziam parte da sociabilidade e do repertório de lazer dos moradores, promovendo conteúdos, falas e participantes alheios ao cotidiano do bairro.

Marlene, moradora da região e frequentadora do samba, me disse: "É estranho ver muita gente de fora aqui. A gente tá mais acostumada com o nosso movimento". Pergunto a ela "como é esse estranhamento" e ela me responde: "É o pessoal, muitas pessoas daqui não gostam de ver esses branquinhos de fora andando por aqui". Nas imediações da associação há uma biqueira. ${ }^{17} \mathrm{O}$ incômodo com a "circulação dos branquinhos" não emerge em razão de haver pessoas se dirigindo para a biqueira, como poderia parecer à primeira vista, pois devido ao comércio de drogas é comum ver gente circulando por ali. O fato que introduz o elemento de evitação é a presença dos de fora, que "chegam tomando conta da nossa área" como se fossem de dentro. A proposição de ações, discursos e conselhos para a comunidade também parece não ser bem recebida quando emitida sem as devidas mediações e sem ter a assistência de um membro da associação. "Esses caras são cheios de ideias", diz um morador, gesticulando com a mão e buscando imitar os movimentos de uma boca próxima à sua orelha. O morador manifestava com isso certo descontentamento com os discursos proferidos no sarau, sobretudo os de conteúdo eminentemente político. Alguns moradores que são frequentadores da associação chegaram a reclamar para Márcio em tom jocoso: "E aí? E essa playboyzada invadindo nossa quebrada?".

Cabe observar que o grupo de dentro da associação, ou seja, aqueles que a frequentam ou são seus "frentes", também se segmentam entre os que são apenas moradores e lá vão para uma partida de bilhar, beber ou 
conversar; aqueles que estabelecem relações de proximidade com a associação auxiliando nos trabalhos de montagem dos equipamentos para o samba ou contribuindo com serviços para a manutenção do prédio; e os membros que comandam a entidade e que têm compromissos que extrapolam o âmbito local. Na ordem da sociabilidade que se desenvolve naquele espaço apresenta-se um conjunto complexo de relações entre aqueles que são mais ou menos próximos à entidade e os que, vindos de fora, tentam entrar ou exercer alguma ação político-cultural na associação ou na "comunidade".

Ao longo de minha pesquisa sempre contei com o auxílio de Márcio (36) para ter informações e acesso a essa associação. Foi um processo que exigiu tempo para que algum grau de confiança pudesse ser consolidado em nossa relação. Inicialmente, as informações me chegavam de forma esporádica, por um comentário extemporâneo, uma declaração sobre um acontecimento, e se efetivavam sobretudo pela minha observação de campo. Com o avançar da pesquisa e minha recorrente presença na associação, as relações com os diferentes membros da entidade foram tomando forma e consolidando uma mútua confiança.

Durante uma parte do período de minha etnografia nesta associação eu acompanhei basicamente o samba e o sarau. São duas situações distintas nas quais mudam o público, os símbolos de pertencimento, as percepções sobre aquele espaço, as interações e as intenções quanto a ele e seus frequentadores. Descrevi que o sarau era pouco frequentado e até evitado por alguns moradores. Por seu lado, o samba não era frequentado pelos militantes e participantes do sarau. Eram dois eventos que abarcavam grupos de estilos distintos ocupando o mesmo espaço, em dias alternados e com pouca interlocução. Diante desse contexto se observa que nos dias de sarau a associação é ocupada por dois grupos com percepções e preocupações bem distintas. Um grupo é formado pelos rapazes que são de dentro, pertencentes ao bairro e que comandam a Associação Vila Conceição. Eles expressam sua afeição e dedicação ao samba e ao futebol de várzea. Voltam sua energia e sua ação para a logística dessas atividades. Em relação ao sarau, participam cedendo o espaço e garantindo a infraestrutura de som, imagem e funcionamento do bar. Pouco se manifestam acerca de questões de ordem ideológica ou política que emergem no sarau. O outro grupo é formado por militantes, organizadores e frequentadores do sarau. Estes, ao contrário daqueles, têm um discurso permeado pelos signos oriundos do espectro das esquerdas. Suas preocupações giram em torno das questões da igualdade e do fim das injustiças - temas que orientam seus trabalhos na região.

Observei em minha pesquisa de campo que a relação entre esses grupos era pontual, circunscrita à realização do sarau e não se estendia 
para outras situações. Havia cordialidade, mas não integração. A etiqueta era cumprida, permitindo que o espaço fosse cedido para a realização do sarau. Contudo, o ingresso dos militantes naquele espaço não alterou substancialmente as lógicas de sociabilidade local, e os grupos se mantinham em seus lugares.

Em certa terça-feira cheguei à Associação Vila Conceição na companhia de um grupo de jovens militantes que prestavam apoio à organização do sarau. Causou algum desconforto a Márcio, que estava acostumado a me encontrar no samba, me ver na companhia do grupo. "E aí, virou poeta?", inquiriu-me jocosamente. O tom irônico adotado por Márcio identificando-me com os frequentadores do sarau indicava naquele momento certo estranhamento em relação aos participantes desse evento organizado na associação. Sua fala apontava também o estabelecimento de algum tipo de marcação de diferença entre aqueles que ele chamava de poetas e os frequentadores habituais da associação, aos quais Márcio, depois de muitas idas a campo, me incluíra. Entre uma conversa e outra com os membros de cada grupo acabei por fixar a atenção em Márcio, que narrou a seguinte história:

- Domingo ${ }^{18}$ depois que você foi embora, teve a maior treta aqui.

- O que aconteceu? Alguma briga?

- Pior. Meu irmão tava aqui no samba. Você viu ele, né? Ele tava na fila do banheiro, aí um cara foi lá furar a fila na frente dele. Ele falou: "Aí, mano, respeita a fila aí". Então o cara falou: "Eu sou irmão e não vou respeitar fila porra nenhuma". "Ah, mano... vai sim. Cê pode ser irmão, mas tem outros irmãos aqui que respeitam todo mundo. Cê não vai passar na frente de ninguém". Meu irmão falou isso pro cara. E eu aqui no balcão não tava sabendo de nada. Aí o cara foi pro fim da fila; meu irmão foi pro banheiro e tal. Saiu e veio aqui pro balcão. Daqui a pouco o cara foi no banheiro também. Só que quando ele saiu, ele tentou furar meu irmão.

- Como?

- Com isso aqui (mostrou-me um cabo de vassoura quebrado com uma farpa pontiaguda em uma das extremidades). Tava lá no banheiro. O cara quebrou e veio pra cima do meu irmão. Aí foi aquele pega pra capar. Meu irmão desviou. Não pegou em cheio, mas deixou uma marca roxa. Gritaria pra todo lado. "Aí, Márcio, ajuda aí. O cara tá querendo me furar", gritou o meu irmão. Malandro... pulei esse balcão, nem sei como, e fomos pra cima do cara cobrindo na porrada. O Dirceu veio para cima pra separar a confusão.

- "Segura, aí Márcio, segura aí. Para. Para. Vamos ver isso direito".

- "Segura o caralho". 
- Eu queria debulhar o cara. Aquela correria. A mulherada apavorada. Resumindo: apartaram. Cada um prum canto. Cada um na sua. Pacificamos. Todo mundo acalmou. O samba começou de novo. Beleza. Só que teve um otário que foi dar uma arma pro cara. Você acredita? Lá fora. O cara jogou um oitão na mão do cara. Só que viram e vieram me avisar. Aí eu pensei: "E agora? O que eu vou fazer?". Bom, aí liguei pro Maurício. Já te apresentei pra ele?

- Não.

- Uma hora vou te apresentar. Ele é o chefe aqui na área. Falei pra ele: "Olha, tem um cara armado aqui". Cê tá ligado que aqui não pode ter arma. Já te falei isso, não falei? Cê já viu alguém armado aqui?

- É, sei sim. Nunca vi arma por aqui.

- Então contei pra ele do cara, coisa e tal. Toda a treta. Aí ele subiu pra cá com uma sacola dessas de feira cheia de armas e foi distribuindo. Chegou, já me deu uma e eu botei na cintura. O Dirceu, o Banjo, todo mundo. Até você, se tivesse aqui, ia entrar no rolo. Ninguém sabia qual era a do cara, mano!

- Ele é aqui da quebrada?

- O cara é do Maringá (bairro vizinho). Irmão de lá, mas isso a gente só soube depois. Mas até aí foi aquele pega. Todo mundo ligando pra todo mundo. Todo mundo de celular na mão. Uns caras que eu nunca tinha visto foram chegando aí. E todo mundo com celular na mão ligando pra cá e pra lá. Falamos com o Carlos direto lá no Presidente Venceslau. ${ }^{19} \mathrm{E}$ aí já começou um debate aqui mesmo na rua. Todo mundo falando. O pessoal do cara dando a versão dele, meu irmão e nosso pessoal dando a nossa. Aí chegou um tiozinho. Tiozinho mesmo. Baixinho, magrelo, todo tatuado, e ficou só olhando. Parado assim (Márcio cruza os braços sobre o peito e segura o queixo com uma das mãos). Depois que todo mundo falou, ele pediu a palavra. Ele falou assim, na maior humildade e tava todo mundo nervoso! O tiozinho, no maior respeito, pediu licença e começou a falar. "Posso dar a minha opinião?". "Claro, fala aí". Mano, aí ele falou: "Eu sou o fulano". Quando ele falou o nome dele, foi aquele silêncio. Ele é um dos fundadores do partido, tá ligado? Só de falar o nome já foi aquele silêncio. Ele não é nem da torre. Tá pra cima. Sei lá onde, mano. Só sei que todo mundo respeita e aceita o que ele fala. Aí ele elogiou a gente pela força que a gente dá pros irmãos e deu uma enquadrada nos caras e já marcou o debate para a segunda-feira. Tá tendo debate todos esses dias. Três dias e continua hoje. Eu nem consegui falar com meu irmão para saber o que deu. O que decidiram. Ontem veio um cara aqui saber se tava tudo certo com a gente. Ele falou assim: "Eu tô ligado que vocês andam pelo certo. Respeitam a disciplina. Todo mundo aqui. Então a gente vai decidir pelo melhor". Agora nem sei o que deu. E olha que domingo tava cheio de irmão aqui, mano! Foi foda segurar os caras. Mas no fim deu tudo certo. Acabou bem... 
Márcio narrava o episódio, interrompendo sua fala quando alguém se aproximava do balcão. Seu comportamento tentava ocultar dos militantes o ocorrido no domingo. Enquanto isso, o grupo que organiza o sarau se movimentava arrumando cadeiras, aparelho de som e iluminação. Dois militantes penduravam cartazes de movimentos sociais e sob estes montavam uma mesa com camisetas e livros para serem vendidos. O público do sarau chegava aos poucos para mais uma noite de poesia, discursos pró-Pinheirinho e apresentações de música e dança seguindo o estilo hip hop.

A entrada do sarau na associação permitiu que dois grupos a frequentassem, em especial nos dias de sarau. Esses grupos apresentam nuances e segmentações internas de acordo com a maior ou menor aproximação do grupo que compõe a associação e em função do pertencimento àquele espaço e ao território. De um lado, os jovens militantes organizadores do sarau e que somente a frequentavam às terças-feiras e, de outro, os membros da associação.

Estes agrupamentos apresentam também nítidas distinções quanto às motivações e aos tipos de práticas engendradas no local. Quanto às segmentações, os de fora, em especial, enfrentam ainda um conjunto de situações impeditivas ou que criam dificuldades para sua ação coletiva, como o acesso ao bairro, certo estigma expresso na designação "playboy", ou simplesmente "boy". Apesar de serem marcados com esses denominativos e das dificuldades daí oriundas, os militantes conseguiram instituir o sarau como uma ação regular que possibilitou sua entrada e sua permanência na associação. Mesmo convivendo com essa segmentação - de dentro/de fora - um ambiente de negociação permitia que as atividades dos de fora seguissem seu curso, ao passo que a associação continuava com suas atividades rotineiras.

No dia em que Carlos (32) - um diretor da associação - saiu da prisão, eu pude observar que os membros dos diferentes grupos e suas segmentações participaram da comemoração pelo seu retorno ao bairro. Era dia de sarau e poucas pessoas sabiam que ele estava na "comunidade". Quando cheguei, o clima era de festa na associação e cada um que entrava recebia a notícia de que Carlos estava em casa e subiria para a sede em breve. As pessoas que vinham comemorar foram se reunindo no andar de cima, ao mesmo tempo em que chegavam outras para participar do sarau. Em dado momento, houve uma mobilização para fazer um churrasco, o que envolveu os jovens organizadores do sarau, um grupo de militantes da cultura e jovens funcionários do tráfico. A festa foi organizada no andar superior da associação. Desse modo, o ambiente ficou dividido entre a festa para Carlos no andar de cima e o sarau no térreo. 
Homens de diferentes idades e lugares chegavam a todo o momento, demonstrando muita emoção e alegria, abraçando-se efusivamente com fortes tapas nas costas. Travessas recheadas de carne e a cerveja desciam do andar superior e circulavam pelo sarau. Nesse dia ninguém pagou para comer ou beber. Os organizadores do sarau se dividiam participando dos dois eventos autorizados por Márcio. De maneira geral, os militantes aparentavam algum constrangimento em subir, mas, por outro lado, se viam na impossibilidade de negar o convite. Subiam e rapidamente voltavam para o térreo onde ocorria o sarau. Desse modo, a associação vivia ao mesmo tempo dois ambientes, quase dois mundos, não fosse o trânsito que alguns personagens faziam entre um piso e outro estabelecendo os fios de ligação entre os atores - papel que Márcio e Dirceu desempenharam por todo o tempo em que durou a comemoração.

Após o convite de Márcio, eu subi e tomei umas cervejas com "os caras". "Sobe lá, Gilberto. Você é de casa!". As conversas giravam em torno do futebol, da associação, das melhorias para a comunidade, das eleições, da "força que o pessoal do Antunes (vereador com grande presença na região) dá pras favelas". A festa avançou pela madrugada com mais e mais pessoas chegando a todo momento.

O retorno de Carlos à associação coincidiu com o período das eleições e, nesse momento, o grupo do vereador Antunes se fez muito mais presente nas atividades da sede. Embora anteriormente o vereador fosse próximo da entidade, inclusive com emenda parlamentar voltada para a construção de um campo de futebol para o time da associação, a presença de seus auxiliares não era tão marcante como passou a ser desde a saída de Carlos da penitenciária. A partir desse dia um assessor do vereador começou a frequentar a associação regularmente e agia como um fiscal das atividades ali desenvolvidas. A ele, por mais de uma vez, eu ouvi Carlos explicar o que estava fazendo: "Vou lá embaixo cuidar para que os moleques não tirem a faixa", em alusão ao bloqueio colocado para impedir o trânsito.

Percebi então que a realização do sarau passava por dificuldades. Inicialmente um evento semanal começou a ser feito em um ritmo inconstante até ser extinto. Fortaleceu-se a divisão entre o grupo que assumia a associação e aqueles que organizavam o sarau. Vinculados a movimentos ou a partidos políticos do campo das esquerdas, os organizadores do sarau sempre se opuseram ao grupo do vereador Antunes. Ele manteve alguma aproximação com a associação, prática que desenvolve em toda a região, angariando apoio político. A despeito dos esforços dos organizadores do sarau, naquele momento a entidade mudava a forma de trabalho, voltando- 
-se exclusivamente para o vereador e abandonando a perspectiva de ação implementada pela dupla Márcio e Dirceu. Estes visavam ocupar ao máximo a estrutura da associação por meio de várias atividades voltadas para diferentes públicos. O ponto central dessa escolha de atuação era o business, e não uma posição ideológica próxima aos militantes. Quanto maior a quantidade de atividades e a de pessoas circulando pela sede, maior o rendimento obtido pela associação. Na nova situação prevalecia a ideia de que a aliança política com o grupo de Antunes poderia ser vantajosa e trazer maiores dividendos ao grupo.

A partir do momento em que o sarau deixou de ser realizado, Bruno não foi mais visto nos espaços que costumava frequentar, fato que trouxe certa preocupação entre os militantes até descobrirem que ele estava em viagem. Com isso, tive que recorrer a outros envolvidos com o sarau para tentar saber o que ocorrera desde a perspectiva dos militantes. Desse modo, recorri à Associação das Mulheres, cujos jovens apoiavam a organização do sarau, e tive a seguinte conversa com Antônio:

- O Bruno desistiu do sarau?

- Teve umas tretas com os caras lá da Conceição. Eles tão mais preocupados com a marca deles lá e cê tá ligado que nós não estamos nessa de marca.

- Mas o sarau leva o nome Conceição e isso os torna mais conhecidos. Eles não acham isso bom?

- Leva, mas pra eles não é o suficiente. Eles querem a marca, não é nem o nome que conta. A gente vai ter uma reunião com eles pra discutir isso. Estamos esperando o Bruno aparecer pra ir lá.

- Tem também a presença do pessoal do Antunes lá, não?

- É isso também. Os caras da associação correm com ele. Eles tão fazendo as escolhas deles. Então é isso. Pra gente não dá pra dividir o mesmo espaço. E nem eles querem.

Não há relações entre as associações Vila Conceição e Mulheres em Luta, embora alguns militantes tenham auxiliado Bruno na realização do sarau. Essa foi, aliás, a maior aproximação entre as duas entidades, não se estabelecendo qualquer vinculação orgânica entre elas. Devido ao envolvimento com o sarau, os militantes se viram na incumbência de discutir com os membros da Associação Vila Conceição os acontecimentos alegados por Carlos que levaram ao encerramento dessa atividade. Discussão da qual eles não podiam se negar a participar sob pena de romperem os laços que permitiram sua entrada na sede e comprometerem Márcio e Dirceu que, com uma postura mais flexível, a promoveu. 


\section{Cabos eleitorais}

Em uma terça-feira que, segundo a programação, seria dia de sarau, eu visitei a Associação Vila Conceição. Chegando à sede, encontrei Dirceu, Carlos e um homem que eu não conhecia fazendo contas para organizar um evento na associação. A mulher e o cunhado de Carlos estavam na sede, mas não participavam da discussão. Um cavalete do vereador Antunes, agora já reeleito, estava encostado no balcão. Chamava a atenção o tom de agradecimento do artefato: sob a foto do político lia-se a quantidade de várias dezenas de milhares de votos obtidos pelo candidato. "A família Antunes agradece pelo apoio". Abaixo, as fotos de seus familiares. Esse cavalete repetia o mesmo texto dos cartazes e outdoors espalhados pela região. O agradecimento pelos votos expressava o reconhecimento pelo apoio de seus eleitores. Ao mesmo tempo, parecia sinalizar o estabelecimento de uma dívida de gratidão, retroalimentando uma lógica eleitoral amparada na troca de favores.

Ao mobilizar o nome da família, amplia-se para seus demais membros a participação na vitória, também recebedores de vultosa soma de votos em outras eleições. Desse modo, insere os filhos na esperada retribuição da dádiva eleitoral em forma de auxílios e serviços prestados pelo vereador e família no atendimento de demandas locais por meio do acesso e da mobilização do aparato do poder público. A fórmula tem surtido os efeitos esperados pelo grupo de Antunes, que não apenas se reelegeu com uma votação acima da centena de milhar de votos, mas também beneficiou seus filhos: um eleito para a Assembleia paulista e outro para a Câmara federal.

Depois de ficar por um tempo encostado no balcão esperando acabar a reunião, perguntei a Carlos o que ocorrera para não ter o sarau.

- Nós tivemos uns problemas aí com o sarau.

- Como assim? Não tava dando lucro?

- Isso também. Não dava muito lucro, não.

- Não valia a pena ficar com o sarau aqui?

- Nós tivemos uns problemas aí com o cara que tava de frente no sarau. Ele tava usando o nome da sede para pegar dinheiro na prefeitura ${ }^{20}$ e não ficava nada aqui pra gente. Isso não dá.

- Mas ele conseguiu algum dinheiro?

- Não sei. A gente foi atrás e descobriu isso de ele tá buscando dinheiro na prefeitura com o nome da sede.

- E qual é o problema?

- O cara não falou com a gente. Ele usa a sede, o nosso nome pra buscar dinheiro e não fala nada pra gente. Não, isso não pode. 
- E agora? Como vai ser?

- A gente tá esperando ele aparecer pra se explicar. Pra gente ver se retoma o sarau. Qual que é a dele. Mas ele não apareceu ainda. Usar nosso nome e não deixar nada pra gente não dá, não é mesmo? Além disso, o cara tinha é que tá aí, aparecer aí pra trocar umas ideias com a gente. Dizer qual é que é a dele.

Evidencia-se que em um mesmo período diferentes atores - militantes, assessores, irmãos, moradores - compartilhavam o espaço e participavam dos eventos promovidos pela associação, buscando, em alguma medida, o desenvolvimento de ações naquele espaço e junto aos moradores.

Dois episódios contribuíram para as mudanças nas interações entre os agentes da Associação Vila Conceição. O primeiro foi a chegada de Carlos, egresso da prisão, e o segundo, o alinhamento da associação com a candidatura de Antunes. Episódios que ocorreram quase concomitantemente no ano de 2012 e tornaram perceptível a maior presença de assessores do candidato nas atividades desenvolvidas pela associação.

No dia em que Carlos comemorava seu retorno ao bairro, um assessor do vereador me disse: "não tem pra ninguém. Favela é Antunes". A frase pode ajudar a compreender o engajamento da associação com o candidato e o afastamento do grupo de militantes do sarau. Segundo esse assessor: "favela é Antunes, porque ele é o único político que faz pela quebrada". Com forte atuação na região, esse parlamentar se notabilizou por viabilizar quadras e campos de futebol nas periferias, conquistando apoio entre os diversos times de futebol de várzea. Durval, presidente da associação Vila Zélia e cabo eleitoral do vereador, diz: "não é só campo de futebol, não. O Antunes faz muita coisa pela região". A categoria fazer aparece aqui como o elemento que justifica o alinhamento com o candidato. ${ }^{21} \mathrm{O}$ parlamentar apresenta certa praticidade em sua ação política, o que implica solucionar problemas e apresentar os resultados aos moradores, mesmo quando a obra ou a benfeitoria não é fruto de seu trabalho - fato comum e muito criticado pelos seus adversários. Esse comportamento político do vereador se diferencia do discurso dos militantes voltado para questões de ordem ideológica e genéricas ou que enfatiza o preceito de que "é preciso a comunidade se organizar para lutar por seus direitos", como dizem eles. Organização que do ponto de vista de Dirceu havia: "A gente tá conversando com um político aí pra agilizar nosso campo. A gente tá organizado com o foco nisso. Agora acho que sai".

No entorno da associação e por toda a região a presença de Antunes se faz pela profusão de material com sua foto, nome e número. Mesmo antes e após o período eleitoral essa presença é muito marcante, pois parte do material permanece afixada nas fachadas das casas e nos estabelecimentos 
comerciais. Com uma ampla rede de colaboradores, esse político é onipresente na região. Sua marca é o apelo à família da zona sul e o agradecimento da família Antunes a todos que lhe conferiram o voto. Nas últimas eleições foi o único candidato a espalhar outdoors agradecendo pelos milhares de votos que recebera. Como já foi observado em outros trabalhos, o parlamentar pode ser compreendido como um mediador entre as associações e o poder público na obtenção de recursos. ${ }^{22}$ Apesar disso, a lealdade ao candidato não é automática nem impede que em situações específicas outros candidatos ou parlamentares sejam acionados. Em meu ambiente de pesquisa, a lealdade ao político é construída a depender das relações que são estabelecidas com os grupos no calor das disputas políticas, daquelas que se estabelecem no cotidiano e da efetiva solução dos problemas que envolvem as associações, apesar da ação pragmática do vereador.

Ao acompanhar as reuniões da Associação de Vila Zita, próxima à Vila Conceição, o nome do parlamentar foi mencionado diversas vezes, dando a impressão de que a associação seria comandada por ele. Os compromissos políticos que ligam o diretor da associação ao parlamentar também suscitam essa impressão, mas não permitem dizer que a relação é automática e definitiva. O mesmo diretor que incentivava as pessoas a participarem da associação afirmava que um "bom motivo para isso é que a gente tem o vereador do nosso lado", e alertava todos sobre os perigos embutidos nas relações com os parlamentares.

Tem que tomar muito cuidado, porque a gente tá aqui trabalhando e vereador é doido pra abraçar o trabalho da gente. Eles vêm de mansinho e, quando a gente menos espera, eles abraçam o que a gente fez e são eles que levam a fama. Aqui não vai ter isso, não. A associação é nossa, é do povo. Agora, quando chegarem as eleições, a conversa é outra. Aí cada um apoia quem quiser e tudo bem.

Ao instituir um sujeito indefinido em sua fala, Durval parece alertar para qualquer vereador, incluindo, assim, seu candidato e qualquer outro que queira se apropriar da associação. Seu depoimento sinaliza a existência de diferentes temporalidades na política, ${ }^{23}$ mas também aponta que existem áreas e espaços políticos a serem conquistados no interior da região de predomínio de determinados políticos. Durval explicita que a área está sob o controle e a influência do líder comunitário. Aos assessores e ao político cabe a conquista da simpatia dessas lideranças para que eventualmente se transformem em cabos eleitorais do candidato. Embora seja outra associação, essa descrição auxilia na compreensão das ligações entre militantes e irmãos na Associação Vila Conceição e na transformação destes em cabos eleitorais. 
Tornar-se cabo eleitoral não está relacionado necessariamente a uma opção ideológica, mesmo em se tratando de militantes com vinculações partidárias. A conexão de militância entre Bruno e Antônio não implicou alinhamento direto com candidatos apoiados ou originários dessas organizações.

O foco da gente é na quebrada. É construir a luta aqui, não adianta ficar fazendo a política nos partidos e esquecer da luta no bairro. É por isso que pra gente é difícil definir um apoio direto a algum candidato. Mesmo porque nenhum candidato desses aí está muito preocupado com as bases (Antônio).

Os militantes estabelecem uma clara distinção entre o trabalho de militância e o trabalho para algum candidato, quando então eles se transformam em cabos eleitorais. A militância é perene e segue o tempo da política de base, ao passo que o trabalho do cabo eleitoral é sazonal, de acordo com o calendário eleitoral. No entanto, cabe lembrar que são temporalidades que estão em interação. A ênfase nas diferenças entre a política de base e a política institucional é uma maneira de os militantes ordenarem o universo da política e suas ações no ambiente onde se desenvolve a ação coletiva.

As relações políticas são um campo aberto de possibilidades para os membros das diferentes associações, não implicando lealdades imediatas. $O$ acesso do político à associação está mediado pelo reconhecimento por parte do candidato das ações engendradas pelas lideranças e pelos militantes e pelo reconhecimento da autonomia da associação.

Os membros da Associação Vila Conceição trabalharam para o candidato Antunes durante a campanha eleitoral. A presença de assessores do candidato dava a tônica das ações da associação por meio da entrega de materiais de campanha, cartazes e cavaletes para serem distribuídos pelas ruas do bairro. Isto não impediu que fossem estabelecidas relações com políticos identificados com o campo dos partidos de esquerda e que, na iminência da repressão a uma festa na comunidade, eles tivessem buscado contatar um parlamentar do PT para intermediar a negociação junto à administração municipal e à Polícia Militar para a realização do evento. Segundo se expressou Dirceu: "A gente tem que ver o nosso lado. Quem pode desenrolar pra gente". Essa maneira de interagir com os políticos sinaliza que os vínculos que os moradores estabelecem com eles são contingentes e marcados pela ambivalência. O alinhamento com o chefe político local não é linear e dado de antemão como exclusivo. Os atores locais não descartam a possibilidade de estabelecer ligações com políticos que não tenham vínculos com o grupo ou mesmo de campos opostos do espectro político do candidato apoiado nas eleições. Da perspectiva dos atores, a ação com vistas à resolução de proble- 
mas muitas vezes imediatos é a chave para acionar os políticos. Neste caso, ao mesmo tempo em que conectavam o parlamentar petista por sugestão de um militante, buscavam contatos com assessores do vereador Antunes, acionado no âmbito local como um representante da "comunidade".

\section{Considerações finais}

A relação entre os jovens militantes e/ou ativistas do campo cultural com os "irmãos" é marcada por um conjunto de ambiguidades, e não pode ser confundida com algo nebuloso, carente de distinções, limites e marcadores sociais que estabeleçam fronteiras, embora haja dualidade e interação entre os diferentes locais de ação e os grupos que compartilham os espaços apresentados neste trabalho. Marcela, jovem militante, afirmou: "No nosso coletivo a gente avaliou que não dava certo misturar as coisas. Essa aproximação com o lado errado da vida só podia trazer problema". Referindo-se ao Sarau da Conceição, seu grupo ponderou sobre as dificuldades de se "realizar um trabalho político naquela comunidade, mas já que os meninos começaram, a gente foi acompanhando. A gente sabia que ia ser difícil se manter ali".

O desafio que os jovens militantes se colocam é o da realização daquilo que eles compreendem como o seu trabalho político. Quando a Associação Vila Conceição passava por transformações evidenciadas na reformulação dos papéis de mando com a saída da prisão de um de seus membros, perguntei a Pedro sobre a presença do crime e a realização do sarau. Ele respondeu: "Veja, a gente não é bobo. A gente sabe que os caras tão lá, mas isso não impede a gente de fazer nosso trabalho". Talvez o que cause estranheza seja o fato de os militantes não terem em sua agenda política o combate ao crime e, em especial, ao tráfico de drogas como um inimigo a ser vencido.

Não tem essa não. Deixa os caras fazendo o movimento deles. A proposta não é acabar com os caras. A gente quer fazer o nosso trabalho. Se vai surtir algum efeito na molecada, é o que importa. A ideia não é acabar com os caras, mas fazer o que a gente se propõe, que é levar cultura, fazer um agito pros moleques verem que há outras possibilidades (Marquinhos, 39 anos, músico atuante no Sarau Vila Conceição).

A ação desses militantes se desenvolve a partir de uma concepção de tomadas de posição no interior do território. A perspectiva política adotada é que sua ação cultural possa vir a apresentar outra compreensão do mundo 
e, portanto, a abertura de um campo de possibilidades para a molecada, seja a que está no tráfico, sejam as crianças que moram na localidade.

A gente faz o nosso trabalho pra mostrar outras possibilidades pros moleques. Apresenta a poesia, o rap, os caras que tão ganhando dinheiro com arte. Coisas feitas por gente da quebrada. O moleque vai se quiser. Tem o sarau das crianças também. Que é pra mostrar pra ele desde pequenininho que tem outras paradas (Bruno).

Do mesmo modo que compreendem sua ação como algo voltado para a apresentação de "outras possibilidades para os moleques", há também um entendimento de que a "comunidade" tem seu próprio tempo político. Bruno diz: "Veja, os caras quiseram o fim do sarau. Não tem problema. A nossa luta continua. Vamos fazer outros saraus em outros lugares. Agora tem que entender o lado dos caras. Eles têm o tempo deles para entender as coisas. É o tempo da comunidade".

Os espaços de atuação dos "irmãos" e dos militantes estão delimitados e compreendidos como espaços distintos de disputas cuja temporalidade é um fator considerado na ação coletiva dos militantes. Concomitantemente, a valorização do pertencimento ao bairro, as relações vicinais e os laços de amizade contribuem para a afirmação de alguns compromissos entre as partes, mesmo em meio aos conflitos pelo predomínio nos espaços. Avaliando a entrada dos militantes na Associação Vila Conceição e a realização do sarau, Antônio faz a seguinte ponderação:

Como que é essa relação, como se dá essa entrada? De alguma forma. Mas não se deu do nada. O Bruno tem uma relação com a Vila Conceição desde criança. No começo do sarau, por exemplo, a Tereza estava bastante forte. A Tereza nasceu ali, mora ali desde pequena. Então, acho que tem várias relações anteriores que possibilitaram isso. Não foi que apareceu do nada. Agora é de fato conflituoso. Mas ali na Conceição o bagulho é louco. Mas acho que o conflito se dá numa relação simbólica muito maior do que com os caras, de embate com os caras.

Antônio avalia que a ação desenvolvida por meio do sarau foi uma rica ação política que contribuiu para a comunidade, apesar das vicissitudes enfrentadas pelos militantes e das relações nebulosas, por fim conflituosas, com os membros da associação.

A ação política é rica. As pessoas da comunidade reconhecem aquela ação política como rica. Apesar de ter vários problemas pessoais por lá, porque o sarau 
tem disso. Começou levando um monte de pessoas que não eram comuns àquele ciclo. Mas eu não vejo isso como grande problema, não. Um dos problemas que o sarau enfrentou é o de levar o nome, tá ligado? Não de ele acontecer ali em si. Mas é dessas questões simbólicas. Pelo contrário, mano, os caras da Conceição também contribuem para a luta política de alguma forma (Antônio).

A utilização do nome da associação para disputar editais da prefeitura sem que isto fosse comunicado aos seus membros levantou suspeitas e contribuiu para o fim do sarau, como foi abordado anteriormente. Quando Antônio se refere ao simbólico, é ao nome que ele se reporta, compreendido como um patrimônio construído pelas pessoas que comandam a associação.

Questões relacionadas ao mundo das ilicitudes e das ilegalidades não são discutidas pelos militantes, que o compreendem como uma parcela da comunidade.

Mas tem vários conflitos, tem vários temas que não são colocados. Tem várias questões, mas também não é nosso papel pôr essas questões para serem debatidas. Nós estamos ali para outra coisa. Inclusive, para a gente, o que interessa mais é a comunidade em si. Mas as pessoas que estão no crime também são da comunidade, mas não são a maioria (Antônio, 29/AML).

Os militantes incorporam ao campo de possibilidades da política essa nova configuração social: os moradores que estão envolvidos com o mundo do crime. Os militantes ponderam o tempo como um item de sua relação política com a comunidade e o próprio posicionamento dos membros da associação como um elemento que responde ao tempo. Isto não significa que os militantes ajam movidos por uma ética originária da fragmentação do mundo operário e seus valores. Parece-me que ocorre um cálculo político para a ação e uma percepção menos imediatista para seus resultados. Como diz Bruno: "a comunidade tem seu tempo". Contudo, cabe destacar que o mando daquele que detém a possibilidade do uso da violência é algo difícil de enfrentar e torna a correlação de forças bastante desequilibrada.

Após um ano e meio de seu encerramento, o sarau foi retomado na associação. Seus organizadores retornaram à sede a convite de Carlos e Dirceu. Segundo este último, "o sarau vai ser quinzenal e é o mesmo pessoal que vai tocar. Teve umas tretas aí, mas tá tudo normalizado. Trocamos uma ideia com eles pra voltar o sarau". Da perspectiva de Bruno, "quem está levando o sarau é o nosso grupo, mas vamos fazer esse e depois vai ficar por conta da comunidade. Eu quis mais mostrar qual era a nossa. Retomar foi uma prestação de contas do sarau pra comunidade". 
Aparentemente, ocorrera alguma negociação para a retomada das atividades e, cuidadoso, Bruno não queria se precipitar e dizer que o Sarau da Vila Conceição voltara à ativa. De todo modo, percebe-se uma ação de lado a lado no sentido de se estabelecer uma nova relação entre as partes.

Eu vou ter que esperar um pouco pra ter certeza do que eles querem, porque eu fui perseguido politicamente por um militante do Antunes. Eles sabem disso. Se eles lavarem as mãos, caso aconteça de novo, eu tô fora. Deixa eles se virarem pra fazer o sarau. Senão a gente chega junto e vamos tocar o sarau pra comunidade (Bruno).

Esse episódio demonstra que a ação coletiva dos jovens militantes da periferia é constituída por um movimento pendular, marcada por idas e vindas próprias do jogo e das temporalidades da política, mas também dos modos de vida juvenis. A metáfora do ioiô proposta por Pais (2001), que expressa as dinâmicas juvenis acerca do mundo do trabalho e do futuro caracterizadas pela incerteza, parece se aplicar igualmente à atuação não só incerta, mas também maleável dos jovens que se apropriam das brechas abertas no campo das relações sociais ou no universo da política para exercerem sua ação.

As perspectivas que justificam o fim do sarau quase se opõem aos acontecimentos, porém um aspecto é evidenciado na fala de Carlos: há um código de confiança que parece ter sido rompido em função de Bruno não ter comunicado sua ação junto à Secretaria de Cultura da Prefeitura. A confiança depositada por Márcio nas atividades do sarau implicava um compromisso de trocas. De um lado, a cessão do espaço para a atividade e, de outro, o retorno financeiro para a associação. Parece que se estabeleceu uma relação de reciprocidade e lealdade que foi rompida pelo organizador do sarau no que diz respeito aos membros da Conceição, desencadeando toda a celeuma. Evidencia-se um conjunto de regras de relacionamentos entre os membros da associação e os que vêm de fora que não é acionado da maneira esperada e com o devido respeito. Estas regras implicam expor a ordem das ações; explicar iniciativas e movimentações que não são por todos entendidas a priori, como os programas de apoio e incentivo mobilizados pelos militantes, os quais a Associação Vila Conceição desconhecia até os acontecimentos que redundaram no término do sarau.

Ao ser perguntado sobre os novos rumos que havia tomado o Sarau da Vila Conceição, Antônio (29/AML) parece não se incomodar e, de certo modo, ironiza a situação de Bruno: 
É como eu falei. Teve umas tretas lá com os caras. Nós marcamos de ir lá conversar com eles, mas estamos esperando o Bruno. Tão dizendo que ele viajou, mas a gente sabe que ele já voltou. Estamos esperando ele pra ir lá. Ele deve tá com medo. Mas não tem erro, não. Se não tiver mais o sarau na Conceição, pode ser até que fortaleça o sarau da Tereza, ${ }^{24}$ ou outros por aí. Porque sarau tem uma pá pra gente fortalecer.

De fato, o término das atividades e a expulsão do grupo de jovens militantes da Associação Vila Conceição não representaram o fim de suas ações político-culturais na região. Eles passaram a promover novos saraus em outros lugares com o mesmo ímpeto e sentido imputado àquele recém-terminado, sinalizando, assim, um tipo de nomadismo circulante de sua ação por diferentes locais, tais como praças, associações e coletivos culturais. O caráter contingente das ações impetradas pelos jovens militantes na região demonstra certa capacidade de recriação da militância política, que usa a cultura como recurso de entrada nos espaços associativos. Há certo senso de oportunidade por parte dos militantes, que buscam aproveitar as brechas para o exercício de sua ação política. Desenvolve-se um uso tático (Certeau 2011) das atividades resguardadas pelo termo cultura com vistas à conquista de posições políticas no interior dos espaços associativos e do bairro.

As descrições etnográficas apresentadas permitem perceber a ocorrência de disputas pela ação hegemônica no território, embora o grupo que liderava o sarau tenha sido praticamente expulso da associação. As alegações de parte a parte possibilitam antever um desentendimento sobre as proposições de cada lado e uma forte injunção do grupo ligado ao vereador Antunes. No entanto, isso não nos autoriza a afirmar que o fim do sarau foi apenas uma consequência da presença de grupos rivais no interior da associação.

Outros elementos surgem para compor esse quadro. A chegada de Carlos, a entrada do "pessoal do Antunes" e o fim do sarau são eventos que se estabelecem concomitantemente no período eleitoral. Nele, os jovens militantes ficaram extremamente ocupados e demandados pelas diferentes forças políticas à esquerda, e muitos atuaram como cabos eleitorais. A Associação Vila Conceição passou a fazer campanha para Antunes e parte de seus membros também se transformou momentaneamente em cabo eleitoral do candidato. O embate político entrou em outra dimensão: outro tempo da política (Palmeira 2002) ganhava preeminência na cena pública e começava a comandar as ações de todos que naquele momento se transmutavam em cabos eleitorais de seus candidatos. 
À medida que o calendário eleitoral avançava, as definições dos papéis políticos ganhavam algumas ambivalências. As diferentes temporalidades da política se mesclavam em um jogo de sobreposições de acordo com o contexto. Os militantes passavam a desempenhar diferentes posições no jogo político da região, procurando ocupar os espaços que então se abriam para o desenvolvimento de sua ação coletiva. O mesmo se pode dizer dos irmãos que se propuseram a defender e a trabalhar para determinados candidatos comprometidos com suas demandas, fossem elas a conquista de um campo de futebol ou melhorias para a comunidade.

Percebe-se, assim, que se institui um campo de disputas políticas que se entrelaçam na orientação pela conquista de espaços no território, e também nas disputas pela conquista de mandatos parlamentares para seus respectivos candidatos. Essa disputa mobiliza militantes e irmãos que se transformam, nesse tempo da política, em cabos eleitorais. Ser cabo eleitoral implica uma série de compromissos com o candidato: distribuição de folhetos e santinhos com sua foto, permitir e promover a colocação de faixas e cartazes na fachada das casas, se necessário angariar recursos financeiros, participar de reuniões de campanha e, muitas vezes, estabelecer uma relação de lealdade. "Não tem pra ninguém. A gente sabe de cada voto que a gente ganha. Quando a comunidade corresponde, o vereador se lembra da comunidade, senão... já sabe. Ele vai se preocupar com quem está com ele, certo?

- E como vocês sabem quem votou?

- Com a urna eletrônica é só olhar o mapa. Eu vou lá e vejo a escola onde vota essa comunidade. Se o voto for pequeno, a gente chega junto e pergunta para o responsável o que houve, se foi corpo mole, se ele não trabalhou o candidato direito na área dele.

Essa fala sinaliza a importância que os cabos eleitorais têm para a entrada dos candidatos em cada área da periferia. Como apontou Vidal (1999:178), são os cabos eleitorais os responsáveis pelo acesso do candidato aos bairros, pois eles são os intermediários entre a população e a máquina administrativa ou eleitoral. Indica também o controle que os candidatos e seus cabos eleitorais exercem sobre as associações que estão em sua área de ação. Como se viu, é possível comprovar uma eventual pequena dedicação à campanha do candidato. Caso ele seja eleito, o empenho do grupo será lembrado no atendimento de suas demandas. A contagem dos votos via mapa eleitoral permite ao vereador instituir o teor dos acordos com as associações e dos atendimentos a elas. As relações entre militantes e irmãos se processam através de lógicas de diferenciação e integração (Bhabha 2005) e não apenas por reciprocidade, 
compromissos e lealdades ou, de outro modo, pela exclusão e o estabelecimento de oposições dicotômicas. Trata-se de um imbricado jogo de poder em que medidas e recursos são assimétricos, mas não inviabiliza ou oblitera a ação política que desde longa data é praticada nas periferias da cidade.

Recebido em 21 de março de 2016

Aprovado em 23 de junho de 2016

Gilberto Geribola Moreno é pesquisador do Núcleo de Antropologia Urbana LabNAU do Departamento de Antropologia da Faculdade de Filosofia, Letras e Ciências Humanas da Universidade de São Paulo, São Paulo/SP, Brasil. E-mail: <geribolamoreno@gmail.com>

\section{Notas}

1 Trata-se de minha pesquisa de doutorado "Tudo que a gente faz na quebrada é política": vida associativa nas bordas da cidade, defendida em 2014 no Programa de Pós-graduação da Faculdade de Educação da Universidade de São Paulo. A pesquisa contou com apoio financeiro do CNPq.

2 Sobre a emergência e a consolidação do PCC, ver Feltran (2008); Biondi (2010); Teixeira (2012).

3 Os trabalhos de Feltran (2008) e Biondi (2010) têm problematizado a ideia do crime ou do mundo do crime como fenômeno apartado de outras esferas da vida social. Os autores apontam um conjunto de relações entre o mundo do crime e a sociedade abrangente, sobretudo as periferias da cidade, que não permite pensar o crime como elemento dicotômico em relação a outras esferas da vida social como, por exemplo, o mundo do trabalho. Os atores apontam novas dimensões éticas e morais na vida das camadas populares que permitem certa movimentação entre os diferentes universos que compõem o mundo das legalidades e ilegalidades; dos lícitos e ilícitos. Godoi (2010), seguindo esta linha de argumentação, usa da metáfora dos vasos comunicantes presentes nos experimentos de física hidráulica para ilustrar as relações entre o mundo do crime e as demais esferas da sociedade. Assim como os anteriores, este autor nos mostra a fragilidade de se pensar o crime a partir de pares de oposição dicotômica.

4 Segundo Arendt $(2001,2007)$, onde há predomínio da violência há a impossibilidade da política. Respeitando a percepção nativa, compreendo que, neste caso específico, a violência entra nos cálculos da ação. 
5 Para um detalhamento sobre os saraus nas periferias da cidade de São Paulo, ver Nascimento (2010); Bin (2009).

6 Respeitando-se o anonimato, todos os nomes de pessoas e associações foram trocados. Para facilitar a localização dos atores pelo leitor, os nomes estão acompanhados de sua idade e vínculo associativo abreviado. Por exemplo: AML para Associação Mulheres na Luta, AS para Sarau do Alfredo. Maurão é o codinome de um dos organizadores de um dos principais saraus periféricos.

7 Seria incorreto falar em direção para esta associação, embora estes dois atores exerçam papéis próximos a esse tipo de atividade. Segundo a própria definição de Márcio (36): "Eu sou um tipo de gerente aqui" e Dirceu (32) é "um frente" da associação.

8 Acompanhei o Sarau da Vila Conceição desde o seu início nessa associação. O relato que faço está escrito no presente, porém, no momento em que escrevo este relato, o sarau deixou de ser realizado. Mais à frente exponho os motivos.

9 Trata-se de informativo distribuído gratuitamente em diferentes espaços associativos e que contém parte da produção cultural que tem origem nas periferias. Dividido em seções, há informações sobre rodas de samba, posses de hip hop, teatro, sarau etc.

10 Trata-se de uma referência ao Pinheirinho, uma área ocupada por trabalhadores sem teto na cidade de São José dos Campos. O processo de reintegração de posse foi marcado por uma ação extremamente violenta por parte da Polícia Militar do estado de São Paulo.

11 O Movimento Luta Popular tem conexões com os partidos do campo das esquerdas e seu propósito é reunir os movimentos sociais de vários estados em uma espécie de congregação desses movimentos, segundo depoimento de alguns participantes, entre eles, Márcia (25), Bruno (28) e Armando (26).

12 Este político tem sua base eleitoral na região na qual exerce uma ação baseada na troca de favores com os eleitores. Nas últimas eleições, elegeu-se com dezenas de milhares de voto, sendo um dos vereadores mais bem votados do município. Dado seu capital político, ele conseguiu eleger dois filhos para cargos legislativos: um para a Assembleia Legislativa do Estado de São Paulo e outro para a Assembleia Legislativa Federal.

13 As relações conflituosas entre moradores estabelecidos e os recém-chegados foram observadas por Elias \& Scotson (2000). Embora aqui não sejam novos moradores, a aproximação aos conceitos de "estabelecidos e outsiders" auxilia a compreensão das dinâmicas de aceitação e recusa entre os atores.

14 Não discrimino quais são as ONGs para manter o seu anonimato em harmonia com a opção para os demais atores presentes no artigo. 
15 A noção de etiqueta desenvolvida por Marques (2002) faz referência a um conjunto de códigos de convívio entre iguais e diferentes. A autora aponta o uso desses códigos como um dispositivo voltado para a evitação da violência na região em que desenvolveu suas pesquisas no estado de Pernambuco. Adoto essa noção neste trabalho por compreendê-la abrangente, de modo que pode comportar a noção de LHP (Lealdade, Humildade e Procedimento) enfatizada pela sociologia como dispositivo ordenador das relações nas periferias e que, em certa medida, foi observada por mim em meu ambiente de pesquisa. Do mesmo modo, a noção de respeito ou de proceder. Compreendo que a noção de etiqueta comporta a possibilidade de maior interação e possibilita a percepção de certa sutileza na relação de mando e obediência, abarcando um conjunto maior de manifestações e interações sociais.

16 Durante a pesquisa de campo minha entrada nessa associação foi precedida de negociação com um membro que me fora apresentado por uma moradora do bairro. Em Moreno (2010) faço um relato de minha primeira aproximação do local.

17 Ponto de venda de drogas.

18 Aos domingos ocorre nessa associação o Samba da Conceição. Este é o evento com maior frequência de moradores, sobretudo jovens, na associação. Durante minha pesquisa de campo eu nunca observei a presença dos militantes que organizavam o sarau.

19 Referência ao Presídio de Presidente Venceslau no interior do estado de São Paulo.

20 Segundo pude apurar, Bruno buscava apoio financeiro junto ao VAI, programa de Valorização de Iniciativas Culturais da Prefeitura da Cidade de São Paulo. Para maiores informações: http://www.prefeitura.sp.gov.br/cidade/secretarias/cultura/ fomentos/index.php? $\mathrm{p}=7276$

21 Vidal (1999) observa essa mesma categoria ao pesquisar a favela Brasília Teimosa, na cidade de Recife.

22 Esta relação é discutida em Kuschnir (2000).

23 Palmeira (2002) discute os tempos da política. Em contraponto com a sua observação, sinalizo que é constitutiva da própria prática política exercida pelos membros das associações a compreensão de que a política se faz em tempos distintos. Há um tempo da ação no bairro, outro do intercâmbio com os órgãos públicos, outro ainda do estabelecimento de relações com parlamentares e/ou candidatos etc.

24 Tereza é manicure e cantora. Iniciou alguns meses antes do fim do Sarau Vila Conceição um encontro de poetisas da periferia, no qual elas apresentavam suas produções. Essa atividade se desenvolve na garagem de sua casa. Embora tenha relações com os membros da Associação Mulheres em Luta, Tereza não é militante 
e quando não está no trabalho ou nos saraus pode ser encontrada em uma igreja evangélica onde professa sua fé.

\section{Referências bibliográficas}

ARENDT, Hannah. 2001. A condição humana. Rio de Janeiro: Forense Universitária. 2007. O que é política? Rio de Janeiro: Bertrand Brasil.

BHABHA, Homi K. 2005. O local da cultura. Belo Horizonte: Ed. UFMG.

BIONDI, Karina. 2010. Junto e misturado: uma etnografia do PCC. São Paulo: Editora Terceiro Nome.

BIN, Marco Antônio. 2009. As redes de escritura nas periferias de São Paulo: a palavra como manifestação de cidadania. Tese de Doutorado em Antropologia, PUC-São Paulo.

CALDEIRA, Teresa Pires do Rio. 1989. A política dos outros: o cotidiano dos moradores da periferia e o que pensam do poder e dos poderosos. São Paulo: Brasiliense.

CARDOSO, Ruth. 2011. Obra reunida. Org. de Tereza Pires do Rio Caldeira. São Paulo: Mameluco.

CERTEAU, Michel de. 2011. A invenção do cotidiano. Petrópolis: Vozes.

ELIAS, Nobert \& SCOTSON, John L. 2000. Os estabelecidos e os outsiders: sociologia das relações de poder a partir de uma pequena comunidade. Rio de Janeiro: Jorge Zahar.

DAGNINO, E. 2004. "Confluência perversa, deslocamentos de sentido, crise discursiva". In: Alejandro Grimson (org.), La cultura en las crisis latinoamericanas. Buenos Aires: Clacso. pp. 195-216.

DURHAM, Eunice. 2004. "A sociedade vista da periferia". In: A dinâmica da cultura. São Paulo: Cosac Naify. pp. 377-407.
FELTRAN, Gabriel de Santis. 2008. Fronteiras de tensão: um estudo sobre política e violência nas periferias de São Paulo. Tese de Doutorado em Ciências Sociais, Unicamp, São Paulo. GODOI, R. 2010. Ao redor e através da prisão: cartografias do dispositivo carcerário contemporâneo. Dissertação de Mestrado em Sociologia, USP, São Paulo.

HOLSTON, James. 2013. Cidadania insurgente: disjunções da democracia e da modernidade no Brasil. São Paulo: Companhia das Letras.

KUSCHNIR, Karina. 2000. O cotidiano da política. Rio de Janeiro: Jorge Zahar Ed.

MARCUS, George. 1995. "Etnography in/of the word system: the emergence of multi sited ethnography". Annual Rewiew of Anthropology, 24:95-117.

MARQUES, Ana Claudia. 2002. Intrigas e questões: vingança de família e tramas sociais no sertão de Pernambuco. Rio de Janeiro: Relume Dumará.

MARTUCCELLI, Danilo \& SINGLY, François de. 2009. Les sociologies de l'individu. Paris: Armand Colin. .2012. Desafios comunes: retrato de la sociedade chilena y sus indivíduos. Santiago: LOM Ediciones.

MOISES, José Álvaro. 1978. Classe populares e protesto urbano. Tese de Doutorado em Ciência Política, FFLCH, USP, São Paulo.

MORENO, Gilberto Geribola. 2010. Jovens e experiência social na educação de jovens e adultos. Dissertação de Mestrado em Educação, Faculdade de Educação, USP, São Paulo. 
2014. "Tudo que a gente faz na quebrada é política": vida associativa nas bordas da cidade. Tese de Doutorado em Educação, Faculdade de Educação, USP.

NASCIMENTO, Erica Peçanha. 2010. "E tudo nosso"! Produção cultural na periferia paulistana. Tese de Doutorado em Antropologia Social, FFLCH, USP, São Paulo.

OLIVEIRA, F. de \& RIZEK, C. (orgs.). 2007. A era da indeterminação. São Paulo: Boitempo.

PAIS, José Machado. 2001. Ganchos, tachos e biscates. Jovens, trabalho e futuro. Porto: Ambar.

PALMEIRA, Moacir. 2002. "Política e tempo: nota exploratória". In: Mariza Peirano (org.), O dito e o feito: ensaios de antropologia dos rituais. Rio de Janeiro: Relume Dumará. pp. 171-177.

PERALVA, Angelina. 2000. Violência e democracia: o paradoxo brasileiro. São Paulo: Paz e Terra.

SADER, Eder. 1988. Quando novos personagens entram em cena: experiências e luta dos trabalhadores da grande
São Paulo 1970-1980. São Paulo: Paz e Terra.

SPOSITO, Marilia Pontes. 2010. A ilusão fecunda: a luta por educação nos movimentos populares. São Paulo: Hucitec.

TEIXEIRA, Alessandra. 2012. Construir a delinquência, articular a criminalidade: um estudo sobre a gestão dos ilegalismos na cidade de São Paulo. Tese de Doutorado em Sociologia, Faculdade de Filosofia, Letras e Ciências Humanas, USP, São Paulo. TELLES, V. S. \& CABANES, R. 2006. Nas tramas da cidade: trajetórias urbanas e seus territórios. São Paulo: Humznitas.

TELLES, V. S. 2009. "Ilegalismos urbanos e a cidade". Novos Estudos CEBRAP, 84: http://www.scielo.br/scielo. php? script $=$ sci_arttext\&pid $=$ S0101$-33002009000200009 \& \operatorname{lng}=\mathrm{en} \& \mathrm{nrm}$ $=$ iso\&tlng=pt. Acesso em 09/03/2015. VIDAL, Dominique. 1999. La politique au quartier: rapports sociaux et citoyenneté à Recife. Paris: Editions de la Maison des Sciences de L'Homme. 


\section{MILITANTES, IRM ÃOS E CABOS ELEITORAIS: VIDA ASSOCIATIVA E TERRITÓRIO NAS PERIFERIAS DA CIDADE DE SÃO PAULO}

\section{Resumo}

O artigo apresenta e discute as interações entre um grupo de jovens militantes e os membros de uma associação de bairro da periferia da cidade de São Paulo. O material apresentado é originário de uma pesquisa etnográfica multissituada realizada entre os anos de 2010 e 2013 em cinco espaços associativos. Para este artigo, selecionou-se uma associação dedicada ao futebol de várzea e ao samba. Nesse espaço, um grupo de jovens militantes, não pertencente à associação, intentou desenvolver uma ação política através da organização de um sarau. Por meio da apresentação de cenas descritivas, o artigo discute as relações entre os militantes e os "irmãos" que estão à frente da associação. Descrevendo as interações dos agentes que compõem esse espaço associativo, aponto suas perspectivas de ação política em um ambiente marcado pela prevalência de relações assimétricas.

Palavras-chave: Vida associativa, Etnografia, Periferia, Jovens, Política.

\section{MILITANTES, HERM ANOS Y PUN- TEROS ELECTORALES: VIDA ASO- CIATIVA Y TERRITORIO EN LAS PERIFERIAS DE LA CIUDAD DE SÃO PAULO}

\section{Resumen}

El artículo presenta y discute las interacciones entre un grupo de jóvenes mili- tantes y los miembros de una asociación de barrio de la periferia de la ciudad de São Paulo. El material presentado se origina en una investigación etnográfica multisituada realizada entre los años 2010 y 2013 en cinco espacios asociativos. Para este artículo, se seleccionó una asociación dedicada al futbol aficionado y al samba. En ese espacio, un grupo de jóvenes militantes, no perteneciente a la asociación, intentó desarrollar una acción política a través de la organización de un encuentro cultural. Por medio de la presentación de escenas descriptivas, el artículo discute las relaciones entre los militantes y los "hermanos" que están al comando de la asociación. Describiendo las interacciones de los agentes que componen este espacio asociativo, apunto sus perspectivas de acción política en un ambiente marcado por la prevalencia de relaciones asimétricas.

Palabras-clave: Vida asociativa, Etnografía, Periferia, Jóvenes, Política.

MILITANTS, BROTHERS AND CANVASSERS: ASSOCIATIONAL LIFE AND TERRITORY IN THE OUTSKIRTS OF SÃO PAULO

\section{Abstract}

This article presents and discusses the interactions between a group of young activists and members of a neighbourhood association in the outskirts of São Paulo. The data derives from a multi-sited ethnographic research conducted between 2010 and 2013 in five associative spaces. An association dedicated to the practice of amateur soccer (a.k.a "floodplain soccer") and samba music was chosen for this article. In this association, a group of non-affiliated young militants tried to 
develop political action by organizing tive space are thus described, indicating soirées. By presenting descriptive scenes, its prospects for political action in an the article discusses the relationships be- environment marked by the prevalence tween these militants and the "brothers" of asymmetrical relations.

who lead the association. The interactions Keywords: Associative life, Ethnography, among the agents that form this associa- Outskirts, Youth, Politics. 